\title{
THE MEASUREMENT OF GLOMERULAR FILTRATION. CREATI- NINE, SUCROSE AND UREA CLEARANCES IN SUBJECTS WITHOUT RENAL DISEASE ${ }^{1}$
}

\author{
By ALEXANDER W. WINKLER 2 AND JOSÉ PARRA 3 \\ (From the Department of Internal Medicine, Yale University School of Medicine, and the \\ Medical Service of the New Haven Hospital, New Haven)
}

(Received for publication June 26, 1937)

The hypothesis advanced by Rehberg in 1926 (18) that the clearance of creatinine is identical with the glomerular filtration rate in man has stimulated much experimental work in the past decade. But in spite of a considerable body of confirmatory evidence in support of Rehberg's original position, it cannot be said that the actual identity of creatinine clearance with glomerular filtration has been established in man. Chasis, Jolliffe, and Smith (1), Jolliffe and Chasis (9), and Shannon (24) have brought forward certain evidence which they interpret as indicating partial renal secretion of creatinine in man. The studies reported here are concerned with simultaneous creatinine, urea, and (in some cases) sucrose clearances determined in successive consecutive periods. Sucrose was chosen as a substance for comparison with creatinine because its behavior is fairly typical of the whole group of nonmetabolized sugars investigated by Smith and Shannon and their associates $(1,9,10,11,27)$. It may be safely injected intravenously, is readily measured, and is quantitatively recoverable in the urine $(12,13)$. Urea was included because its behavior has been more widely studied than that of any other so-called "clearance" substance.

\section{MATERIALS AND METHODS}

In this study are included only subjects with creatinine clearances in the "normal" range-i.e., greater than 100 cc. per minute. The subjects were normal volunteers and patients with a variety of clinical conditions not directly affecting the kidneys. No attempt was made to standardize the experimental procedure too rigidly, since this would in part have defeated the purpose of the project, viz., to study the variations in the clearances. In

1 This investigation was aided by a grant from the Fluid Research Fund of Yale University, School of Medicine.

2 Alexander Brown Coxe Fellow.

${ }^{3}$ Fellow of the University of Madrid, and Honorary Fellow of Yale University. general the procedure was as follows: At seven o'clock on the day of the experiment the subject was given a single dose of creatinine (10 or 15 grams) and $400 \mathrm{cc}$. of water. From 30 to 60 minutes later 25 or 30 grams of sucrose were given intravenously in $100 \mathrm{cc}$. of water. The first urine, taken between 30 and 90 minutes after the creatinine, was discarded. A blood specimen was then taken, followed at intervals by more specimens of blood and urine until the close of the experiment. Large amounts of water were usually taken during the first hour of the experiment and sometimes even later, so that most of the experiments include a considerable period of water diuresis. When the creatinine was administered intravenously, the collection of urine was started about 30 minutes later. In all the sucrose experiments, the first sucrose period was started at about this same interval after the injection of the sucrose. Exact time and divisions of periods are indicated in the table summarizing the clearances.

No attempt was made to synchronize precisely urine collections and blood specimens, save that in general one blood specimen was secured at the beginning of the first urine period, one at the end of the last urine period, and one or more to correspond to each intervening urine period.

The clearances themselves were calculated by extrapolation. In the actual determination of clearances an instantaneously determined quantity (serum concentration) must be compared with an average quantity (average excretion rate during a definite period). In defining a method applicable to all substances at all serum concentrations an entirely general and self-consistent mode of approach must be employed. The method used here is as follows (Figure 1). The various individual serum concentrations were first plotted against time (asterisks), and a smooth curve EFF'... was drawn through the points. The urine excretion rate was next plotted as a series of straight lines $B C, B^{\prime} C^{\prime}, \cdots$. The area under the serum concentration curve corresponding to each urine period ( $A E F D, D^{\prime} F^{\prime} D^{\prime}, \cdots$ ) was then measured accurately. Each area divided by its abscissa is mathematically the mean value of the serum concentration corresponding to that particular urine collection interval. The clearance was then calculated as urine excretion rate divided by this mean serum figure. The mean clearance thus determined must be distinguished from the instantaneous clearance, which is defined not over a period but rather at a given instant (instantaneous excre- 


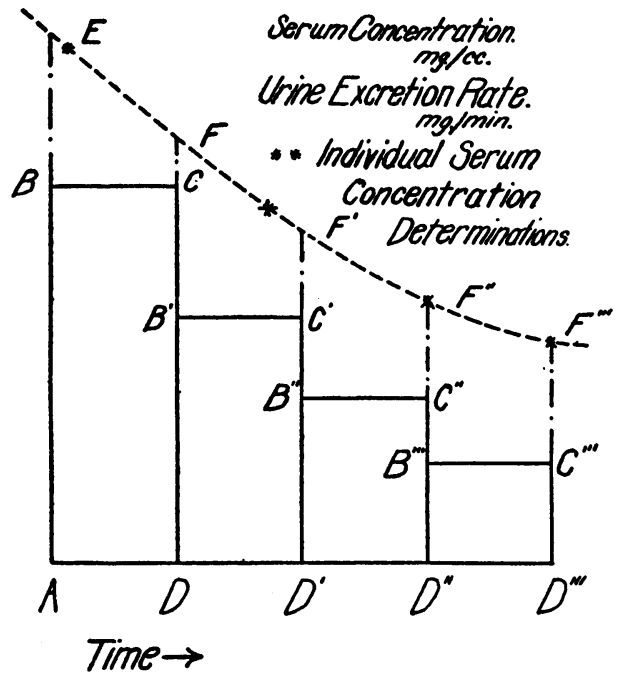

Fig. 1. Method of Calculating Clearances

tion rate: serum concentration). The limit of the mean clearance equals the instantaneous clearance as the time interval during which the urine is collected approaches zero. Any analysis less precise than the foregoing is bound to lead to inconsistencies.

All analyses were made on Folin-Wu tungstic acid filtrates of serum. Creatinine was determined by a slight modification of the original method of Folin $(6,7)$, sucrose as the difference between the concentration of reducing substance before and after acid hydrolysis, measured by the method of Shaffer and Somogyi (21). Serum sucrose values less than 25 to $30 \mathrm{mgm}$. per cent were rejected. Urea in earlier experiments was determined by the aeration method of Van Slyke and Cullen (31), later by the gasometric urease method of Van Slyke (29). These gave substantially the same values for clearances (32). Earlier a simple colorimeter, later a Hastings compensating colorimeter, was employed in the estimation of creatinine; with suitable standards good agreement between the results with the two instruments was obtained. Accuracy in measurement of serum creatinine was greater with high serum creatinine levels; as will be seen from Table I, observations with serum creatinine less than 5 $\mathrm{mgm}$. per cent were excluded and the readings were made preferably in the range of 10 to $20 \mathrm{mgm}$. per cent.

TABLE I $\dagger$

Subjects without renal disease

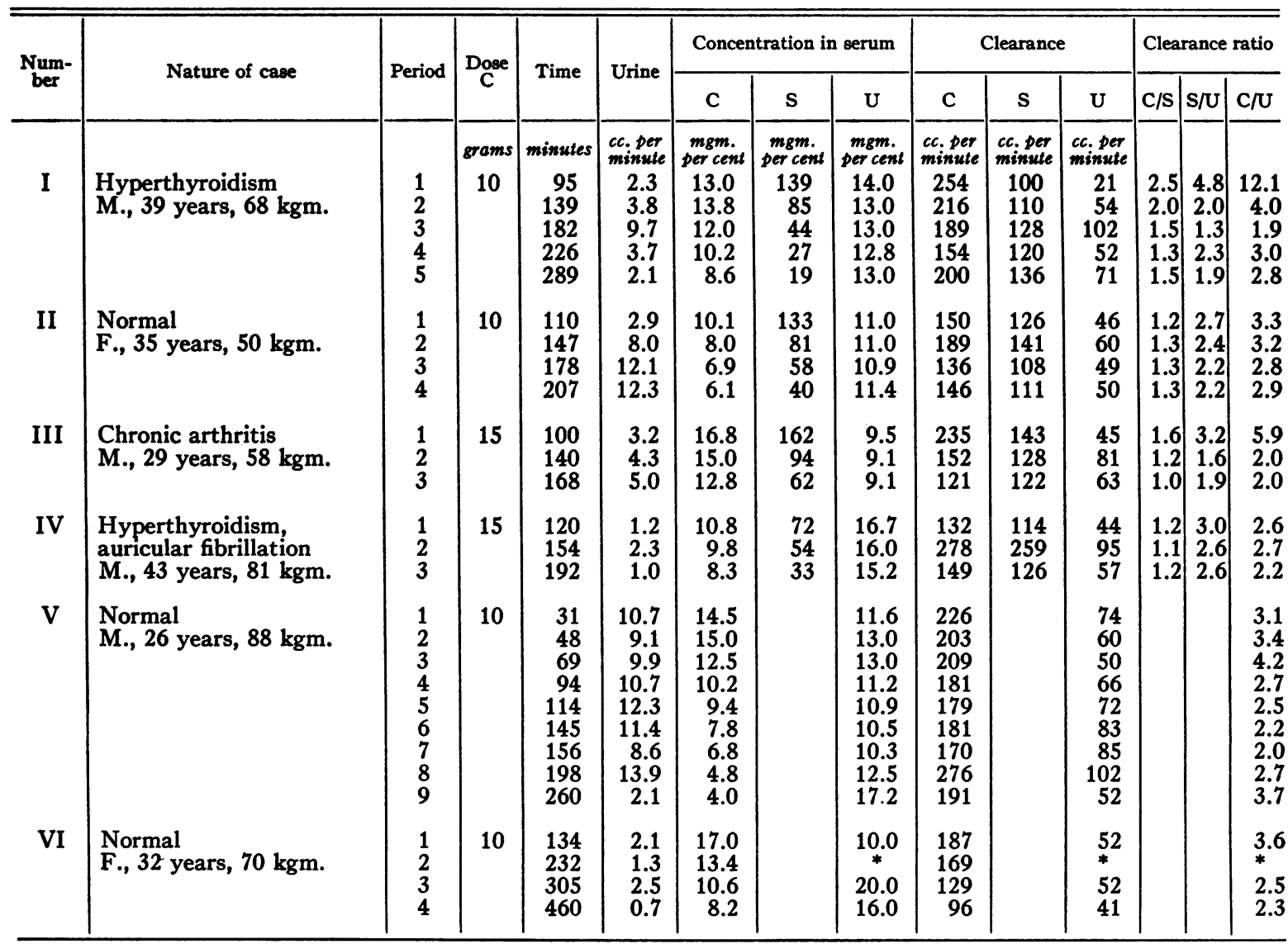


GLOMERULAR FILTRATION

TABLE I-Continued

\begin{tabular}{|c|c|c|c|c|c|c|c|c|c|c|c|c|c|c|}
\hline \multirow{2}{*}{$\underset{\text { ber }}{\text { Num- }}$} & \multirow{2}{*}{ Nature of case } & \multirow{2}{*}{ Period } & \multirow{2}{*}{ Dose } & \multirow{2}{*}{ Time } & \multirow{2}{*}{ Urine } & \multicolumn{3}{|c|}{ Concentration in serum } & \multicolumn{3}{|c|}{ Clearance } & \multicolumn{3}{|c|}{ Clearance ratio } \\
\hline & & & & & & C & $\mathbf{s}$ & $\mathbf{U}$ & c & $\mathbf{s}$ & $\mathbf{U}$ & $\mathrm{c} / \mathrm{s}$ & $\mathrm{s} / \mathrm{U}$ & $\mathrm{C} / \mathrm{U}$ \\
\hline VII & $\begin{array}{l}\text { Rheumatic heart disease } \\
\text { M., } 20 \text { years, } 60 \mathrm{kgm} \text {. }\end{array}$ & $\begin{array}{l}1 \\
2 \\
3 \\
4 \\
5\end{array}$ & $\begin{array}{c}\text { grams } \\
10\end{array}$ & \begin{tabular}{|c|} 
minutes \\
107 \\
154 \\
198 \\
245 \\
302
\end{tabular} & $\begin{array}{r}c c_{.} \text {per } \\
\text { minute } \\
3.8 \\
3.9 \\
10.8 \\
7.0 \\
1.6\end{array}$ & 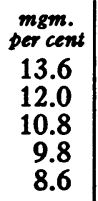 & $\underset{\text { per cent }}{\operatorname{mgm}}$ & $\begin{array}{c}\underset{\text { per cent }}{\text { per }} \\
11.7 \\
* \\
11.2 \\
13.0 \\
12.8\end{array}$ & $\begin{array}{c}c c \text { per } \\
\text { minute } \\
184 \\
183 \\
178 \\
157 \\
145\end{array}$ & $\begin{array}{c}c_{c} \text {. per } \\
\text { pinute }\end{array}$ & $\begin{array}{c}c c \text { per } \\
\text { minute } \\
83 \\
* \\
127 \\
61 \\
63\end{array}$ & & & $\begin{array}{l}2.2 \\
* \\
1.4 \\
2.6 \\
2.3\end{array}$ \\
\hline VIII & $\begin{array}{l}\text { Obstructive jaundice } \\
\text { M., } 50 \text { years, } 55 \mathrm{kgm} \text {. }\end{array}$ & $\begin{array}{l}1 \\
2 \\
3 \\
4\end{array}$ & 10 & $\begin{array}{l}153 \\
203 \\
247 \\
317\end{array}$ & $\begin{array}{l}0.6 \\
0.7 \\
0.8 \\
0.8\end{array}$ & $\begin{array}{r}14.3 \\
11.2 \\
9.4 \\
8.0\end{array}$ & & $\begin{array}{c}* \\
38.6 \\
39.5 \\
32.1\end{array}$ & $\begin{array}{l}139 \\
149 \\
143 \\
155\end{array}$ & & $\begin{array}{l}* \\
31 \\
38 \\
38\end{array}$ & & & $\begin{array}{l}\text { * } \\
4.8 \\
3.8 \\
4.1\end{array}$ \\
\hline IX & $\begin{array}{l}\text { Cirrhosis of liver } \\
\text { M., } 39 \text { years, } 67 \mathrm{kgm} \text {. }\end{array}$ & $\begin{array}{l}1 \\
2 \\
3\end{array}$ & 10 & $\begin{array}{r}53 \\
97 \\
141\end{array}$ & $\begin{array}{l}1.7 \\
1.2 \\
1.1\end{array}$ & $\begin{array}{l}16.6 \\
13.5 \\
10.4\end{array}$ & $\begin{array}{l}75 \\
42 \\
28\end{array}$ & $\begin{array}{l}14.2 \\
13.0 \\
12.5\end{array}$ & $\begin{array}{l}221 \\
186 \\
185\end{array}$ & $\begin{array}{l}156 \\
149 \\
150\end{array}$ & $\begin{array}{l}85 \\
84 \\
84\end{array}$ & $\begin{array}{l}1.4 \\
1.3 \\
1.2\end{array}$ & $\begin{array}{l}1.9 \\
1.8 \\
1.8\end{array}$ & $\begin{array}{l}2.6 \\
2.2 \\
2.2\end{array}$ \\
\hline $\mathbf{x}$ & $\begin{array}{l}\text { Diabetes mellitus } \\
\text { M., } 31 \text { years, } 57 \mathrm{kgm} \text {. }\end{array}$ & $\begin{array}{l}1 \\
2 \\
3\end{array}$ & 10 & $\begin{array}{r}54 \\
104 \\
171\end{array}$ & $\begin{array}{l}2.4 \\
1.5 \\
1.0\end{array}$ & $\begin{array}{r}24.2 \\
15.0 \\
9.5\end{array}$ & $\begin{array}{l}90 \\
61 \\
33\end{array}$ & $\begin{array}{l}11.6 \\
11.7 \\
12.6\end{array}$ & $\begin{array}{l}197 \\
188 \\
218\end{array}$ & $\begin{array}{l}180 \\
150 \\
162\end{array}$ & $\begin{array}{l}82 \\
76 \\
66\end{array}$ & $\begin{array}{l}1.1 \\
1.3 \\
1.3\end{array}$ & $\begin{array}{l}2.2 \\
2.0 \\
2.5\end{array}$ & $\begin{array}{l}2.4 \\
2.5 \\
3.3\end{array}$ \\
\hline $\mathbf{X I}$ & $\begin{array}{l}\text { Diabetes mellitus } \\
\text { M., } 47 \text { years, } 71 \mathrm{kgm} .\end{array}$ & $\begin{array}{l}1 \\
2 \\
3 \\
4\end{array}$ & 10 & $\begin{array}{r}53 \\
89 \\
120 \\
160\end{array}$ & $\begin{array}{l}4.0 \\
3.7 \\
2.4 \\
2.5\end{array}$ & $\begin{array}{l}25.5 \\
18.0 \\
14.0 \\
10.8\end{array}$ & $\begin{array}{r}135 \\
93 \\
73 \\
55\end{array}$ & $\begin{array}{l}16.1 \\
15.0 \\
14.6 \\
14.8\end{array}$ & $\begin{array}{l}206 \\
167 \\
165 \\
183\end{array}$ & $\begin{array}{l}108 \\
137 \\
107 \\
121\end{array}$ & $\begin{array}{r}100 \\
93 \\
80 \\
88\end{array}$ & $\begin{array}{l}1.9 \\
1.2 \\
1.5 \\
1.5\end{array}$ & \begin{tabular}{|l|}
1.1 \\
1.5 \\
1.3 \\
1.4
\end{tabular} & $\begin{array}{l}2.1 \\
1.8 \\
2.1 \\
2.1\end{array}$ \\
\hline XII & $\begin{array}{l}\text { Hyperthyroidism } \\
\text { F., } 21 \text { years, } 50 \mathrm{kgm} .\end{array}$ & $\begin{array}{l}1 \\
2 \\
3\end{array}$ & 10 & $\begin{array}{r}54 \\
94 \\
135\end{array}$ & $\begin{array}{l}2.8 \\
3.4 \\
4.8\end{array}$ & $\begin{array}{l}26.0 \\
18.5 \\
14.5\end{array}$ & $\begin{array}{r}150 \\
78 \\
46\end{array}$ & $\begin{array}{r}11.5 \\
9.4 \\
9.2\end{array}$ & $\begin{array}{l}168 \\
217 \\
210\end{array}$ & $\begin{array}{l}139 \\
208 \\
207\end{array}$ & $\begin{array}{r}65 \\
94 \\
103\end{array}$ & $\begin{array}{l}1.2 \\
1.0 \\
1 . C\end{array}$ & \begin{tabular}{|l|}
1.4 \\
2.2 \\
2.0
\end{tabular} & $\begin{array}{l}2.6 \\
2.3 \\
2.0\end{array}$ \\
\hline XIII & $\begin{array}{l}\text { Chronic arthritis } \\
\text { F., } 38 \text { years, } 59 \mathrm{kgm} \text {. }\end{array}$ & $\begin{array}{l}1 \\
2 \\
3\end{array}$ & 9 & $\begin{array}{r}60 \\
105 \\
156\end{array}$ & $\begin{array}{l}7.1 \\
4.9 \\
2.6\end{array}$ & $\begin{array}{l}26.0 \\
18.0 \\
12.5\end{array}$ & & $\begin{array}{l}7.2 \\
6.6 \\
6.6\end{array}$ & $\begin{array}{l}204 \\
169 \\
205\end{array}$ & & $\begin{array}{l}76 \\
78 \\
70\end{array}$ & & & $\begin{array}{l}2.7 \\
2.2 \\
2.9\end{array}$ \\
\hline XIV & $\begin{array}{l}\text { Normal } \\
\text { M., } 25 \text { years, } 75 \text { kgm. }\end{array}$ & $\begin{array}{l}1 \\
2 \\
3 \\
4 \\
5 \\
6 \\
7\end{array}$ & $10^{*}$ & $\begin{array}{r}53 \\
89 \\
129 \\
180 \\
235 \\
308 \\
390\end{array}$ & $\begin{array}{l}1.9 \\
2.0 \\
8.0 \\
5.5 \\
2.1 \\
1.2 \\
1.3\end{array}$ & $\begin{array}{r}17.0 \\
12.4 \\
10.1 \\
7.6 \\
6.0 \\
5.0 \\
4.3\end{array}$ & & $\begin{array}{l}17.0 \\
15.9 \\
15.5 \\
15.0 \\
13.7 \\
12.8 \\
11.9\end{array}$ & $\begin{array}{l}215 \\
171 \\
147 \\
141 \\
154 \\
139 \\
149\end{array}$ & & $\begin{array}{l}93 \\
72 \\
90 \\
75 \\
77 \\
74 \\
83\end{array}$ & & & $\begin{array}{l}2.3 \\
2.4 \\
1.6 \\
1.9 \\
2.0 \\
1.9 \\
1.8\end{array}$ \\
\hline
\end{tabular}

* Urea injected intravenously.

$+\mathrm{C}$ stands for creatinine, $\mathrm{S}$ for sucrose, and $\mathrm{U}$ for urea nitrogen. All times are calculated to the middle of the period, and all serum concentration figures are extrapolated values. Italic type indicates that the dose of creatinine was administered intravenously.

\section{RESULTS}

The results of 14 such experiments are presented in Table I. They may be analyzed in several ways.

(a) Variability of the individual clearances. All three of the clearances vary markedly in successive periods in the same individual. There is a definite tendency in 8 of the 14 cases, Experiments I, III, V, VI, VII, IX, XI, XIV, for creatinine clearances to be high in the earlier periods of the experiments and to decline in successive periods thereafter. Of the remainder, four, Experiments II, IV, X, XIII, are steady or irregular, while only two, Experiments VIII, XII, show any tendency to rise. Neither the sucrose nor the urea clearance exhibits any such tendency toward systematic decline, although both vary considerably from period to period. The sucrose clearances are the most stable of the three. The urea clearances are apparently the most variable, but without systematic trend, save with urine flow. The relation to urine flow is considered below.

By the exclusion of creatinine clearances below $100 \mathrm{cc}$. per minute a somewhat arbitrary lower limit has been adopted. It is clear, however, that in subjects with "normal" kidneys the creatinine clearance may range anywhere from 100 to 250 cc. per minute, and that a proportionately wide range exists for the "normal" clearance limits of the other two substances. 
(b) Relation of the clearances to one another. All of these clearances tend to vary together. In other words, the ratios of the clearances to one another are on the whole less variable than the clearances themselves. However, the creatinine clearance, unlike the other two, tends to decline with time. One aspect of this phenomenon is shown in Figure 2, in which the ratio of creatinine:sucrose clearance is plotted against time.

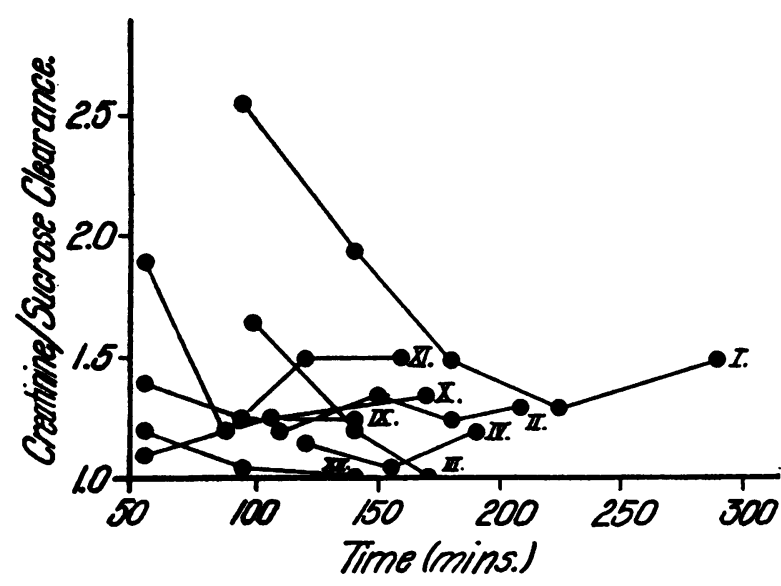

Fig. 2. Variation of Creatinine: Sucrose Ratio WITH TIME

In three of the eight experiments the ratio drops sharply with time, while in two others it falls off moderately. In the other three there is little change. The creatinine: urea ratio is more variable, reflecting the greater variability of the urea clearance (Figure 3 ), but here also the declining tendency of the ratio is noticeable. It seems quite clear that the creatinine clearance declines not only in absolute amount but in relation to the sucrose and urea clearances as well.

In no case is there a departure from the sequence of magnitude, creatinine $>$ sucrose $>$ urea, in spite of the individual variation in the clearances. The creatinine: urea ratio varies from a maximum of 12.1 to a minimum of 1.4 ; but omitting the two highest values which are associated with very low urea clearances and very low urine flow, the upper limit is reduced to 4.0. Within this range all values are found, most of them falling between 2.0 and 3.0. Sucrose clearances in general are somewhat closer to the creatinine than to the urea clearance, the absolute value of the creatinine: sucrose ratio varying from 2.5 to 1.0. The absolute value of the sucrose: urea ratio varies between 4.8 and 1.1 , but the omission of the same pair of low urea clearances reduces the upper limit to 2.7 .

(c) Variation of clearances with urine flow. This is most marked in the case of the urea clearance, at high (greater than 2 cc. per minute) rates of urine flow as well as at low. No evidence of any definite augmentation limit appears from these data. Thus in Experiment I the urea clearance rose as urine flow increased from 3.8 to $9.7 \mathrm{cc}$. per minute, only to fall back to its previous value when the urine flow dropped back to 3.7 cc. per minute. In other instances, as in Experiment II, a phenomenon similar to that observed by Shannon (26) in the dog is seen. As the urine flow increased from 2.9 to $8.0 \mathrm{cc}$. per minute the urea clearance rose, only to drop to its former value with further increase in urine flow. A rise of urea clearance with rising urine flow and subsequent fall with decreasing urine flow occurred in Experiments VII and XIV, and in the last three periods of Experiment V.

It is harder to make definite statements concerning the creatinine and sucrose clearances, especially since the fluctuations of the former with time tend to outweigh other factors. The drop of the creatinine clearance between Periods 8 and 9 of Experiment $\mathrm{V}$ may be taken as an instance when variation of urine flow was associated with similar variation of both the creatinine and the urea clearances, while in the first four periods of Experiment I, sucrose and urea clearances varied directionally with urine flow. Other apparent examples of this sort may be picked out. It is, however, quite clear that the tendency of the creatinine clearance to fall off with time caninot usually be correlated with falling rates of urine flow. Whatever tendency the creatinine and sucrose clearances have to vary with urine flow is much less consistent and less marked than is the case with urea.

The sucrose clearance behaves with respect to variation in urine flow like the creatinine rather than the urea clearance. In other words it does not fall off with very low volumes as consistently as does the urea clearance (30).

(d) Variation of clearances with serum concentration. The sucrose and the urea clearances do not vary systematically with changes in the concentrations of sucrose and urea in serum re- 
spectively. The falling of the creatinine clearances with time is in general directly correlated with a decline in serum creatinine concentration. Since a single large dose of creatinine was given a short period before the commencement of the experiments, and not repeated later, it was inevitable that the serum creatinine be in a declining declined. The existence of so many exceptions to the correlation is strong evidence that the association is accidental, due to the mode of planning of many of the experiments.

(e) Intravenous and peroral administration. Creatinine was given orally in 8 subjects and intravenously in 6 . The peculiar behavior of the

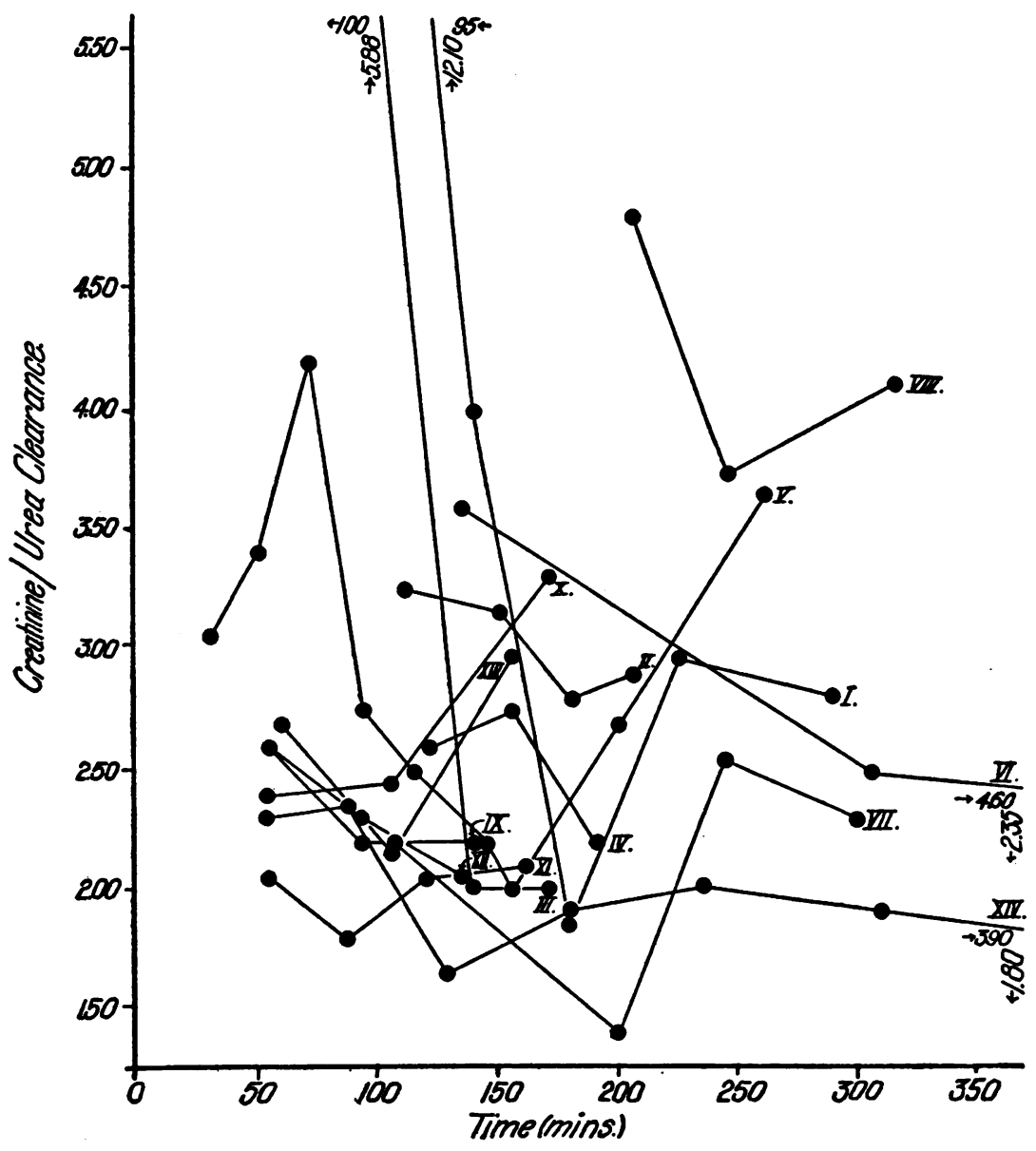

Fig. 3. Variation of Creatinine: Urea Ratio with Time

phase throughout the greater part of the experiments, irrespective of the mode of variations of the clearances. The fortuitous nature of the correlation is indicated by the existence of certain instarices in which the creatinine clearances fell off while the serum concentration was still rising slightly (Experiment I, Periods 1 to 2; Experiment V, Periods 1 to 2 ). In Experiments II and $X$ the serum creatinine fell off while the clearances did not, and in Experiment XII the clearance actually rose while the serum concentration creatinine clearance is equally apparent in both groups. There is no evidence from the experiments that the administration of either creatinine or of sucrose intravenously in the concentrations and amounts used had any appreciable effect on the clearances themselves or on urine flow. In the 4 experiments in which small amounts of urea were injected simultaneously with the creatinine, in one instance only (Experiment VII, Period 3) did the urea clearance rise following the injection.

( $f$ ) Type of case. No definite inference can 
be drawn because of the limited number of conditions represented. The three patients with hyperthyroidism (Experiments I, IV, XII) had rather high clearances with more than the average degree of variability. This is consistent with the observations of others (15).

\section{DISCUSSION}

If two entirely different substances have numerically identical clearance values, a simple explanation for such identity may be found in their common excretion by filtration alone. Any other explanation would be difficult and arbitrary, especially in the face of all the collateral evidence demonstrating the reality of glomerular filtration. Three or more substances having identical clearances would still further increase the improbability of any alternative explanation. It is essential that the substances differ both chemically and physiologically; for example, identity of clearances of several foreign sugars is not nearly such cogent evidence.

In the dog, both the creatinine and the inulin clearances are identical $(19,23,25)$. Also, Van Slyke, Hiller and Miller (33) have recently shown that the ferrocyanide clearance is identical with the clearances of these other two. If the general theory of filtration and reabsorption is accepted, then certainly the burden of proof rests on the shoulders of anyone who would deny that this common clearance of creatinine, inulin, and ferrocyanide represents the actual glomerular filtration rate in the dog. Unfortunately, no such identity is demonstrable in man. Creatinine clearance in man is definitely somewhat higher than that of inulin (24) and much higher than that of ferrocyanide (17). By analogy with the dog it may reasonably be supposed that the glomerular filtration rate is somewhat in the neighborhood of the inulin and creatinine clearances, but the assertion that one or the other of these substances represents the true filtration rate is at present distinctly arbitrary.

At first glance creatinine would seem to be more likely than inulin, because its clearance is somewhat the larger. However, Shannon (24) bases his belief that inulin is simply filtered and creatinine both filtered and secreted, partly on the behavior of the creatinine clearance after phlori- zin $(1,28)$, but more especially on the peculiar behavior of the creatinine: inulin ratio after the intravenous injection of large amounts of creatinine. At the start of these experiments with the serum creatinine at 10 to $20 \mathrm{mgm}$. per cent the creatinine:inulin ratio was about 1.4. Repeated injections of creatinine were given so that the serum creatinine level rose to about $100 \mathrm{mgm}$. per cent, and simultaneously the creatinine: inulin ratio fell to about 1.1 and remained there. This fall in ratio was accomplished almost entirely through a drop in the creatinine clearance, the absolute value of the inulin clearance changing but little. However, as the serum creatinine dropped gradually back to its initial level, the creatinine : inulin ratio remained at 1.1 instead of rising to 1.4 again. Shannon attempts no explanation of this latter effect, but concludes that creatinine clearance varies with serum concentration, and that consequently, in man, the inulin clearance is a truer measure of glomerular filtration than is the creatinine clearance.

In a considerable proportion of experiments here reported the creatinine clearance fell in the successive periods after the administration of the substance both absolutely and relative to the sucrose clearance. Since sucrose behaves as does xylose $(10,11,12)$, yielding clearances constantly 20 or 25 per cent less than inulin, these experiments may be related to those of Shannon just mentioned. In both sets of experiments the initially high creatinine: sugar ratio gradually declined during successive periods, and in both sets this drop was brought about through a decline in absolute value of the creatinine clearance, the sugar clearance remaining practically constant. In Shannon's experiments the decline in ratio is partly associated with rising concentration of creatinine in the serum, while in ours the correlation is, if anything, with a declining serum concentration. The emphasis which Shannon lays on the correlation between absolute serum creatinine concentration and creatinine: inulin ratio is, however, not justified by his own data, since in the later stages of his experiments the serum concentration of creatinine declines from higher to much lower levels without change in the ratio. It appears as though the correlation in his experiments between rising serum concentration and declining ratio were fortuitous, depending on the manner in 
which the experiments were performed. Certainly our results are entirely consistent with those of Shannon; only the common factor with which the drop in the creatinine clearance and the creatinine: sugar ratio may be correlated is not serum creatinine concentration, but time after injection or ingestion. If it be assumed that for some reason creatinine is eliminated at an abnormally high rate after a large exogenous dose, and then at a more usual rate in later periods, the two sets of experiments are entirely consistent.

Abnormally high clearances immediately after giving creatinine have certainly been observed before. The protocols of Chrometzka and Unger (2), of Iverson and Jacobsen (8) and of Medes and Berglund (14) offer examples of this effect. Rehberg's original protocols show the effect to a slight degree (18) as do those of Dominguez and Pomerene (5). Indeed, these latter authors base their major contention on this observation, but interpret it as a minor artificial perturbation due to the inclusion of "endogenous" with "exogenous" creatinine of serum and urine in the usual calculation of clearance. They show that if the clearances are "corrected" by subtracting from the creatinine of serum and urine the endogenous fraction, the progressive decline of values is eliminated. They conclude therefrom that endogenous and exogenous creatinine are excreted by different mechanisms. At the levels of serum and urine creatinine in most of our experiments such endogenous "corrections" are quantitatively very small and certainly fail entirely to bring successive clearances into line. It seems probable that Dominguez and Pomerene were observing a phenomenon similar to that here reported, but were misled by the accidental coincidence of the magnitude of the necessary mathematical adjustment with the normal values of endogenous creatinine. It should be noted that their doses of creatinine as well as those of Rehberg were one-half to one-third as great as ours. Similar considerations apply to the proposed correction of Cope (3), which was to be applied to the serum creatinine values alone.

Some caution is necessary before interpreting these irregular fluctuations in the creatinine clearance as "tubular secretion" over and above glomerular filtration along the lines suggested by
Shannon and Smith. However, an interpretation of these fluctuations as actual changes in glomerular filtration rate makes it very difficult to understand the simultaneous stability of the other clearances. Still another interpretation is possible, viz., that some of the Jaffe reacting substance in the serum is not true creatinine, and that the proportion of this non-creatinine chromogenic substance decreases with time. This is rendered most improbable by the recent demonstration by Miller and Dubos (16) that all the chromogenic substance in normal serum is true creatinine. Clearly an explanation of this type is fanciful; the preponderance of evidence favors tubular secretory activity as the explanation presenting the fewest difficulties.

It cannot be too strongly emphasized that our observations relate only to man. In the dogfish, relatively enormous creatinine: inulin ratios have been observed (22), of an entirely different order of magnitude from those seen in man. This phenomenon may well be due to quite different causes. Some tendency for the creatinine clearance to fall off with time has been observed in dogs by Davenport, Fulton, Van Auken and Parsons (4), and by Schmitz (20). In view of the repeated demonstrations by Shannon and others of the identity of creatinine and inulin clearances in this animal, it is only reasonable to assume that these changes represent actual changes in glomerular filtration rate, and are not comparable to the phenomenon observed by us in man.

The practical implication of our data in the interpretation of single clearances is obvious. Single creatinine clearances, without regard to time after administration, are grossly misleading, if they are assumed to be measures of filtration rate. Urea clearances vary so much with urine flow that all individual clearances must be interpreted with this in mind. And sucrose is presumably reabsorbed to a slight but uncertain extent. Thus, though all these clearances tend to vary together, each is subject to specific perturbing factors. Hence no one of them may be considered an absolute measure of glomerular filtration; yet, subject to the several reservations that have been set forth with each individual substance, they are all relative measures of glomerular filtration. 


\section{CONCLUSIONS}

1. Creatinine, sucrose and urea clearances in man, while subject to considerable variation in the same individual, tend to vary together.

2. The order of magnitude of clearances: creatinine $>$ sucrose $>$ urea is rigidly maintained.

3. Creatinine clearances sometimes tend to be high in periods immediately following the administration of the creatinine, but fall off as time goes on.

4. Sucrose and urea clearances measured simultaneously have no such tendency to decline with time.

5. This peculiar behavior of creatinine probably represents varying tubular secretion rather than varying glomerular filtration.

6. Creatinine, sucrose and urea clearances are, subject to certain limitations inherent in each one, satisfactory relative measures of glomerular filtration. None of them is an absolute measure of glomerular filtration.

7. Individual creatinine clearances must be interpreted with caution.

\section{BIBLIOGRAPHY}

1. Chasis, H., Jolliffe, N., and Smith, H. W., The action of phlorizin on the excretion of glucose, xylose, sucrose, creatinine and urea by man. J. Clin. Invest., 1933, 12, 1083.

2. Chrometzka, $F$., and Unger, $K$., Untersuchungen über die Grösse des Glomerulusfiltrats unter dem Einfluss von Diureticis und Hormonen. Ztschr. f. d. ges. exper. Med., 1932, 80, 261.

3. Cope, C. L., The excretion of creatinine by the human kidney in health and in nephritis. Quart. J. Med., 1931, 24, 567.

4. Davenport, L. F., Fulton, M. N., Van Auken, H. A., and Parsons, R. J., The creatinine clearance as a measure of glomerular filtration in dogs with particular reference to the effect of diuretic drugs. Am. J. Physiol., 1934, 108, 99.

5. Dominguez, R., and Pomerene, E., Studies of the renal excretion of creatinine. I. On the functional relation between the rate of output and the concentration in the plasma. J. Biol. Chem., 1934, 104, 449.

6. Folin, O., On the determination of creatinine and creatine in urine. J. Biol. Chem., 1914, 17, 469.

7. Folin, $O$., On the determination of creatinine and creatine in blood, milk and tissues. J. Biol. Chem., $1914,17,475$.

8. Iversen, $P$., and Jacobsen, E., Untersuchungen über die Ausscheidung der Phosphate durch die Nieren. Skandinav. Arch. f. Physiol., 1935, 71, 260.
9. Jolliffe, N., and Chasis, H., The filtration and secretion of exogenous creatinine in man. Am. J. Physiol., 1933, 104, 677.

10. Jolliffe, N., Shannon, J. A., and Smith, H. W., The excretion of urine in the dog. III. The use of nonmetabolized sugars in the measurement of the glomerular filtrate. Am. J. Physiol., 1932, 100, 301.

11. Jolliffe, N., Shannon, J. A., and Smith, H. W., The excretion of urine in the dog. V. The effects of xylose and sucrose upon the glomerular and urea clearances. Am. J. Physiol., 1932, 101, 639.

12. Keith, N. M., Power, M. H., and Peterson, R. D., The renal excretion of sucrose, xylose, urea and inorganic sulphate in normal men: a comparison of simultaneous clearances. Proc. Staff Meet., Mayo Clin., 1933, 8, 682.

13. Keith, N. M., Power, M. H., and Peterson, R. D., The distribution and recovery of intravenously injected sucrose. Am. J. Physiol. (Proc.), 1934, 109, 62.

14. Medes, G., and Berglund, H., Studies in Rehberg's test for glomerular filtration. In The Kidney in Health and Disease. Lea and Febiger, Philadelphia, 1935, Chap. 15.

15. Medes, G., and Herrick, J. F., Blood flow to the kidney and creatinine clearance. Proc. Soc. Exper. Biol. and Med., 1933, 31, 116.

16. Miller, B. F., and Dubos, R., Enzyme for decomposition of creatinine and its action on the "apparent creatinine" of blood. Proc. Soc. Exper. Biol. and Med., 1936, 35, 335.

17. Miller, B. F., and Winkler, A., The ferrocyanide clearance in man. J. Clin. Invest., 1936, 15, 489.

18. Rehberg, P. B., Studies on kidney function. I. The rate of filtration and reabsorption in the human kidney. Biochem. J., 1926, $20,447$.

19. Richards, A. N., Westfall, B. B., and Bott, P. A., Renal excretion of inulin, creatinine and xylose in normal dogs. Proc. Soc. Exper. Biol. and Med., 1934, 32, 73.

20. Schmitz, H. L., Studies on the action of diuretics. I. The effect of euphyllin and salyrgan upon glomerular filtration and tubular reabsorption. J. Clin. Invest., 1932, 11, 1075.

21. Shaffer, P. A., and Somogyi, M., Copper-iodometric reagents for sugar determination. J. Biol. Chem., 1933, 100, 695.

22. Shannon, J. A., Absorption and excretion of water and salts by the elasmobranch fishes. IV. The secretion of exogenous creatinine by the dogfish, Squalus acanthias. J. Cell. and Comp. Physiol., 1934, 4, 211.

23. Shannon, J. A., The excretion of inulin by the dog. Am. J. Physiol., 1935, 112, 405.

24. Shannon, J. A., The renal excretion of creatinine in man. J. Clin. Invest., 1935, 14, 403.

25. Shannon, J. A., The excretion of inulin and creatinine at low urine flows by the normal dog. Am. J. Physiol., 1936, 114, 362. 
26. Shannon, J. A., Glomerular filtration and urea excretion in relation to urine flow in the dog. Am. J. Physiol., 1936, 117, 206.

27. Shannon, J. A., Jolliffe, N., and Smith, H. W., The excretion of urine in the dog. VI. The filtration and secretion of exogenous creatinine. Am. J. Physiol., 1932, 102, 534.

28. Shannon, J. A., and Smith, H. W., The excretion of inulin, xylose and urea by normal and phlorizinized man. J. Clin. Invest., 1935, 14, 393.

29. Van Slyke, D. D., Determinations of urea by gasometric measurement of the carbon dioxide formed by the action of urease. J. Biol. Chem., 1927, 73, 695.

30. Van Slyke, D. D., Stillman, E., Möller, E., Ehrich, W., McIntosh, J. F., Leiter, L., MacKay, E. M., Hannon, R. R., Moore, N. S., and Johnston, C.,
Observations on the courses of different types of Bright's disease, and on the resultant changes in renal anatomy. Medicine, 1930, 9, 257.

31. Van Slyke, D. D., and Cullen, G. E., The determination of urea by the urease method. J. Biol. Chem., 1916, 24, 117.

32. Van Slyke, D. D., Page, I. H., Hiller, A., and Kirk, E., Studies of urea excretion. IX. Comparison of urea clearances calculated from the excretion of urea, of urea plus ammonia, and of nitrogen determinable by hypobromite. J. Clin. Invest., 1935, 14, 901.

33. Van Slyke, D. D., Hiller, A., and Miller, B. F., The clearance, extraction percentage and estimated filtration of sodium ferrocyanide in the mammalian kidney. Comparison with inulin, creatinine and urea. Am. J. Physiol., 1935, 113, 611. 